\title{
Corruption and Wildlife Trafficking: Three Case Studies Involving Asia
}

\author{
Tanya Wyatt ${ }^{1} \cdot$ Kelly Johnson $^{1} \cdot$ Laura Hunter $^{1}$ • \\ Ryan George $^{1} \cdot$ Rachel Gunter $^{1}$
}

Received: 3 January 2017 / Accepted: 20 July 2017 / Published online: 15 August 2017

(C) The Author(s) 2017. This article is an open access publication

\begin{abstract}
As wildlife trafficking or the illegal wildlife trade has taken a more prominent place on the global agenda, discussions are taking place as to how wildlife trafficking happens. An increased understanding has revealed that corruption is a key facilitator of this profitable and pervasive global black market, but limited research has explored exactly what that corruption looks like and how corruption enables wildlife to be trafficked. Furthermore, research shows that Asia, particularly China and Southeast Asia, are focal points for the supply and demand of certain species of wildlife. Through a literature-based investigation, this paper unpacks the role specific acts of corruption play in the trafficking of ivory, reptile skins and live reptiles from, through or to Asia. It is proposed that not only do individual corrupt acts enable wildlife trafficking to happen, but also that corrupted structures (the criminal justice system, and economic and political foundations) in some societies enable trafficking to happen and also increase the resilience of trafficking to reduction measures. In collating detailed data about the forms of corruption facilitating wildlife trafficking, the gaps in knowledge, and therefore the important areas for further research, become evident.
\end{abstract}

Keywords Corruption · Wildlife trafficking · Green criminology · Reptiles · Ivory

\section{Introduction}

As wildlife trafficking or the illegal wildlife trade has taken a more prominent place on the global agenda, discussions are taking place as to how wildlife trafficking happens. Certainly, there are theoretical explanations for the demand driving wildlife trafficking (TRAFFIC 2008; Wyatt 2013b), but corruption has emerged as a clear facilitator of the illegal trade in wildlife (WWF and TRAFFIC 2015; Wyatt and Cao 2015; UNODC 2016). Corruption is a complex

Tanya Wyatt

tanya.wyatt@northumbria.ac.uk

1 Northumbria University, Ellison Place, Newcastle upon Tyne NE1 8ST, UK 
concept that does not have a universal definition. In drawing on the range of literature regarding corruption, ${ }^{1}$ we considered corruption to consist of any person (public official or private individual) who abuses their position to benefit themselves, people in their network, their community or their organisation. In conducting our literature-based study, we looked for documentation of corrupt acts fitting this definition throughout the current academic, governmental and non-governmental publications available through our University's library database and online. The corrupt acts fall within the broad categories of bribery, patronage, diplomatic cover and permit abuse (Wyatt and Cao 2015). Bribery is the offering of money or gifts in exchange for the person being bribed undertaking one of the acts listed (turning a blind eye, providing information, allowing smuggling and so forth). Patronage also results in turning a blind eye etc., but the actors are connected through a family or friendship network. For instance, rhinoceros ranch owners and veterinarians colluding with poachers and then sharing in the profit of the horn sale (Duffy 2014). Diplomatic cover is the use of an official diplomatic position to engage in trafficking that is difficult to uncover and to stop because of the protected status of these positions. Finally, permit abuse occurs in numerous forms involving fraud, forgery and theft (Wyatt and Cao 2015). As stated above in regard to the definition of corruption, the corrupt actors are from both the public and private sectors (Table 1). They abuse their position to benefit themselves, those close to them or their organisation.

Asia, particularly China and the Southeast, is cited as being key area for both the sourcing and the consumption of illegal wildlife (TRAFFIC 2008; UNODC 2016). As this paper will demonstrate using three case studies of ivory, reptile skins and live reptiles, corruption takes place in every stage of the wildlife trafficking process. These three wildlifes were chosen as they cover some of the range of wildlife market diversity in terms of their form (wildlife part (ivory); processed wildlife product (reptile skins); and live wildlife (live reptiles)), the reason they are in demand (luxury products and pets) and their legal status (it is illegal to trade ivory internationally; reptile skins and live reptiles are legal to trade subject to conditions). With this diversity, we predict that different forms of individual corrupt acts will facilitate the different black markets. Drawing on the research of WWF/TRAFFIC (2015), Wyatt and Cao (2015) and Williams et al. (2016), we propose that the wildlife trafficking process consists of planning, poaching/breeding, distribution, transportation, processing, selling and laundering (see Table 3 which provides a full summary). Not each of these steps will be relevant to every species or market of wildlife, but most wildlife will be subjected to these processes beginning with their death or capture through to being sold.

Importantly though, and one of the biggest challenges for preventing wildlife trafficking, is that often the wildlife trafficking process sits within already corrupt structures that facilitate crime of all kinds. We propose that the criminal justice system, the political environment and the economic environment are the overarching structures that may be corrupted which in turn facilitate trafficking of wildlife and other contraband. It is important to note that these structures, and thus wildlife trafficking, have further social and cultural contexts that also play a role in how prevalent corruption may or may not be. Holmes (2006) notes in the case of many Eastern European countries that corruption is prevalent and expected, but the public when surveyed still perceive the corruption to be

\footnotetext{
${ }^{1}$ For a comprehensive discussion of definitions of corruption see Klitgaard (1988), Passas (1998), Doig and Theobold (2003) or Holmes (2006) amongst others.
} 
Table 1 The corrupt actors and acts in wildlife trafficking

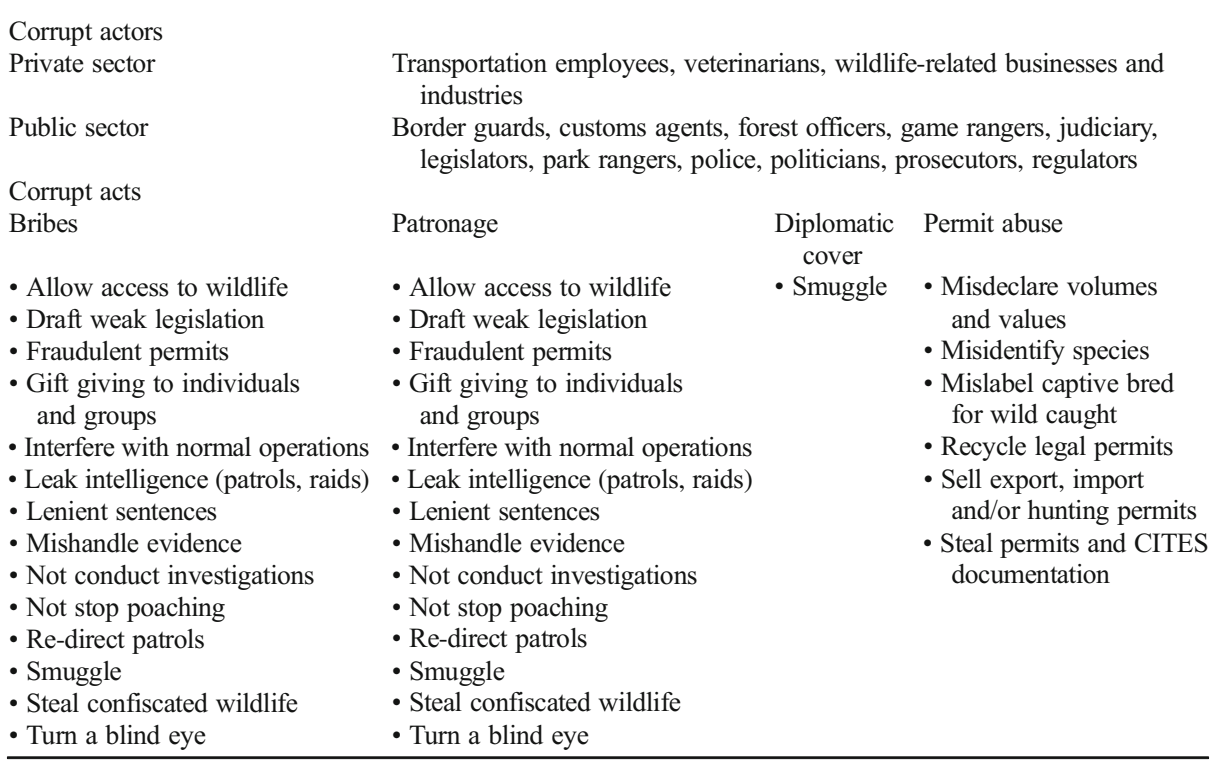

Adapted from Wyatt and Cao (2015)

wrong. Whereas we agree that this is a significant element to the connection between corruption and wildlife trafficking, a full discussion of this aspect is beyond the scope of our paper. We do therefore explore all corrupt acts matching our definition even when these may be viewed as "normal" in the context where the acts are occurring. This article will first analyse the structures we have proposed in which wildlife trafficking takes place before detailing each of the case studies in terms of the specific acts of corruption that are known to be occurring at each of the stages of the process.

\section{Corrupt Structures}

In Table 2, we outline the three structures of society that corrupt or corruptible may provide the basis on which wildlife trafficking can occur. As the table illustrates, these three structures occur in parallel and cover the whole of the society in which wildlife trafficking takes place. The first is the criminal justice system. In the case studies, we will explore instances of individual law enforcement corruption that enable wildlife trafficking. Here, we are investigating the wider criminal justice system and how, if corrupted, this impacts upon wildlife trafficking. Individual law enforcement officers if corrupted may facilitate the trafficking of wildlife from poaching through to selling. Other employees of the criminal justice system may also play a role. Prosecutors and judges may also be corrupt. In the case of prosecutors being corrupt, this may lead to, in the rare instances where wildlife traffickers are arrested and brought to court, acquittals and/or lenient sentences. Instances of wildlife traffickers being arrested and/or processed by the criminal justice system are rare because of the near global phenomena that environmental and 
Table 2 Corrupt aspects and corruptible structures of society that facilitate wildlife trafficking

\begin{tabular}{|c|c|c|}
\hline Criminal justice system & Economics & Politics \\
\hline $\begin{array}{l}\text { - Judicial corruption-no penalties } \\
\text { for IWT } \\
\text { - Law enforcement colluding with } \\
\text { organised crime and traffickers- } \\
\text { stealing evidence and seizures } \\
\text { - Police/rangers not keeping records } \\
\text { of poaching and IWT } \\
\text { - Law enforcement is prone to } \\
\text { corruption because they have } \\
\text { no training, supervision or } \\
\text { ethical guidance } \\
\text { - Corruption and bribe taking } \\
\text { are normative } \\
\text { - Weak ports }\end{array}$ & $\begin{array}{l}\text { - Weak financial institutions } \\
\text { - Weak legislation and enforcement } \\
\text { around money laundering and } \\
\text { tax evasion } \\
\text { - Misappropriation, fraud and/or } \\
\text { embezzlement of wildlife } \\
\text { programme funds }\end{array}$ & $\begin{array}{l}\text { - Politicians colluding with } \\
\text { traffickers and organised crime } \\
\text { - No political will } \\
\text { - Politicians protect traffickers } \\
\text { - Corruption and bribe taking are } \\
\text { normative } \\
\text { - Politicians taking bribes to } \\
\text { make/keep weak legislation; } \\
\text { to make legislation ambiguous } \\
\text { with loopholes }\end{array}$ \\
\hline
\end{tabular}

wildlife crimes are not priorities for law enforcement or criminal justice (Wyatt 2013b; DLA Piper 2014). This leads to a noticeable absence of wildlife criminals being held accountable (Hall and Wyatt 2017).

One of the key issues with corruption within the legislative process is that of discretion within the judiciary. Despite legislation being in place to prevent wildlife trafficking and to prosecute those who commit this crime, it is up to the discretion of the judge to decide on these cases. Additionally, evidence in wildlife trafficking cases may go missing so the cases cannot go forward (Master 2015). For example, an investigation by DLA Piper (2015): 483) highlighted that on several occasions, prosecutions have been either stalled due to evidence tampering or "disappear[ed] from the judicial process once the suspect is granted bail". These are examples after the trafficking has taken place. Also, evident are societies where the legislation itself - the foundation for preventing wildlife trafficking - is weak because of a corrupted legislature that manipulate or maintain legislation that does not address wildlife trafficking and/or corruption.

The Convention on the International Trade in Endangered Species of Wild Fauna and Flora (CITES) and the members of CITES are required to adopt national domestic legislation, to be compliant with the convention, including banning or limiting trade of species listed in one of its three appendices. CITES (2015a) officials acknowledged that there needs to be legislation that links anti-corruption work with that of wildlife trafficking and organised crime as they are not separate entities. The link between corruption, organised crime and wildlife trafficking is important in terms of legislation as it is "crucial to ensure that combating corruption as it affects trade in wildlife and CITES implementation is built into other relevant conventions, national laws, institutions and programmes" (CITES 2015a). At the Conference of the Parties meeting of CITES members in 2016, CITES went even further in its call to action against corruption by passing the Draft Resolution "Prohibiting, Preventing, Detecting and Countering Corruption Facilitating Activities Conducted in Violation of the Convention" (CITES 2016b). The resolution amongst other guidance notes that 15 of the, at the time, 182 convention signatories are not members of the United Nations Convention Against Corruption (UNCAC) and that all signatories to UNCAC are required to "criminalise bribery and a number of related offences" (CITES 2016b: 4). 
Yet there are instances where the political element of societies that provide the basis for legislation is inadequate or not functioning to support the rule of law, i.e. weak governance. The report by DLA Piper (2014) found that national primary legislation was very mixed. It was identified that part of the problem with legislation was that wildlife crime was not always seen as a serious crime, and the report stated that "a law will act as a deterrent only where the penalties for violating that law are proportionate to the prohibited activity" (DLA Piper 2014: 2 ). This is true of wildlife trafficking and corruption. Where there is weak governance generally then, there is the likelihood that this system will be corruptible.

Similarly, a report from the U4 Anti-Corruption Resource Centre (Martini 2013) examined the ways in which wildlife trafficking legislation impacts on poaching and other aspects of the illegal wildlife trade. One of the difficulties with weak regulatory frameworks is that many of the corrupted individuals throughout the process are government actors, for example, officials implementing CITES, government authority figures, public officials and actors within the police and criminal justice system (Martini 2013). These can be considered under so-called petty corruption, where the individual benefits are on a small scale. Yet, there are also instances of grand corruption, where the benefits of the corruption are significant in terms of the bribes being received or because the corrupt official maintains a system from which they receive large benefits (Doig and Theobald 2003). Because of this, it is often a complicated web of bribery and corruption that can be difficult to unravel. Corrupt officials with the power to change or implement wildlife legislation can cause legislation to combat wildlife trafficking to be weak and ineffective as this suits the needs of those (possibly themselves) who wish to benefit financially from this illicit trade. The U4 Anti-Corruption Resource Centre found that some public officials maintain a personal or financial interest in the wildlife trade, and therefore could be able to influence decisions, particularly in regard to legislation, through bribery, exotic illicit gifts such as ivory (Martini 2013) or from direct personal gain from the unchallenged illegal trade.

Whereas corruption can be found in relation to national legislative structures regarding wildlife trafficking, it is also a transnational issue not only because of the movement of wildlife across borders but also because of the transfer of money between countries and to different actors. "Corruption and weak regulatory frameworks may offer several opportunities to criminal organisations to launder the proceeds of crime" (Martini 2013:1). With regard to wildlife, this most likely takes place in those markets where there are legal and illegal parallel markets. For instance, as we will discuss in the case studies below, it is feasible that illegally obtained ivory or illegally caught reptiles are laundered into the legitimate industry by corrupt employees and organisations in order to maximise profits.

In summary, wildlife trafficking occurs within three structural elements of society within which corruption is also prevalent. The wider criminal justice system, not just rangers and law enforcement directly involved with detecting trafficking, may take bribes to acquit traffickers or give lenient sentences. In some places, politicians can directly benefit from the illegal wildlife trade so work to maintain weak wildlife protection legislation or impede and disrupt efforts to improve this legislation. It may not only be wildlife protection legislation that is made weak, it may be too that financial or civil legislation to combat money laundering and corruption is impeded. Individual corrupt acts, as will shortly be detailed in the three case studies, are then at times taking place within criminal justice systems and political and economic structures that are compromised and maintained by corrupt officials (see Table 2). With both macro- and micro-levels of corruption at work, tackling wildlife trafficking is a difficult challenge. 


\section{The Case Studies Involving Asia}

\section{Ivory}

Recent increases in elephant poaching have made "corruption a high profile issue" (Smith et al. 2014: 954), since park staff, enforcement officers and politicians have all been implicated (Gross 2007; Weru 2016). Additionally, it has previously been argued that CITES' index of the "Proportion of Illegally Killed Elephants" (PIKE) documenting countries that have high elephant poaching rates corresponds with countries that also have low Corruption Perception Index (CPI) as calculated by Transparency International scores (Williams and Parry-Jones 2016). Created in 1995, the CPI scores, rated from 100 (very clean) to 0 (very corrupt), determine the extent of corruption in 176 countries' public sector around the world (Transparency International 2017). Furthermore, the EIA (2016: 8) noted that out of the 15 Illegal Wildlife Trade countries, $12(80 \%)$ "had a score of less than 50, indicating high levels of corruption". This case study provides evidence to support that within the ivory trade corruption is present at many of the different trade stages.

The sophisticated criminal networks that are involved with the ivory trade, which frequently span across many international borders, often consist of poachers, mainland smugglers, cross sea smugglers, end market traders and corrupt officials (EIA 2014). Bennett (2014: 56) argues that there are many different governmental "officials demanding bribes for compliance... and accepting bribes to overlook illegal activities". Furthermore, customs officials have been known to switch documents, identification cards and other permits allowing the ivory to pass further along the chain without being noticed as illegal; there are also reports of officials falsifying certificates at the processing or end sale point to allow entry into the legal market (Bennett 2014; DLA Piper 2015; EIA 2014).

Corruption within the ivory trade causes many problems. For example, bribery not only disrupts plans to combat illegal trade, it also hinders the "enforcement of anti-poaching laws, sustainable hunting, and effective land-use planning" (Smith et al. 2014: 954). Embezzlement not only reduces conservation funding levels but also weakens positive incentive for community-based conservation. This is because many of the protected areas in Africa do not contribute to regional poverty reduction (Duffy and St John 2013). Furthermore, decision makers may focus more upon the wishes of donors and elites instead of for the benefit of the conservation programme. "Fraud also diverts and reduces conservation funding and undermines donor confidence by claiming funds for non-existent projects or colluding to avoid paying concession fees" (Smith et al. 2014: 954). Furthermore, cronyism and nepotism reduces ranger staff morale as well as the possibility of illegal activities being reported (Smith et al. 2014). Legal loopholes along the trade chain (Weru 2016) and "oneoff" sales of ivory stockpiles (Gossmann 2009) are argued by some as being one of the main driving forces behind the demand for ivory which ultimately intensifies poaching for and smuggling of ivory (Bennett 2014; EIA 2014; Gossmann 2009). For example, in Chad, the poaching of elephants increased dramatically because of the increasing "acceptability of and access to the global ivory trade" (Gossmann 2009: 55). Yet, CITES argue that the "link between the two one-off legal ivory sales and increasing illegal killing of elephant has not been established by the data presently available", and other "drivers are involved in the ongoing illegal ivory trade" (Martin et al. 2012: vi). We will now draw on the existing literature to provide examples of corrupt activities at each stages of the trafficking process. 


\section{Poaching}

Poaching is often associated with states that exhibit "low levels of law enforcement and high levels of corruption, conflict, political instability, and access to small arms" (Gossmann 2009:58) which also correlates with low CPI scores (Atuobi 2007; DLA Piper 2015; Williams and Parry-Jones 2016). In Uganda, "the demand for and payment of bribes are no longer secret... corruption is becoming an acceptable way of life" (Moreto et al. 2015: 362). It was found that having either relatives or friends who have previously poached influences a ranger's decision in allowing misconduct related to poaching to happen (Moreto et al. 2015). Moreto et al.'s (2015) findings were not specific to just ivory, yet at this point, they cannot be generalised to other protected areas other than the one in their study or to outside of Uganda. Nevertheless, there has been evidence of similar low levels of corruption within the ivory trade elsewhere around the globe. For example, in Kenya, the involvement of rangers in poaching was evident by the Ministry for Natural Resources and Tourism (MNRT) firing "21 game rangers for collaborating with poachers" (EIA 2014: 11). In some instances, outside poachers have been hired in by government officials or local fixers. For example, in 2014, police officials from Mloka (a main entry point for the Selous Game Reserve) hired outside poachers, supplied them with weapons and took delivery of the ivory (EIA 2014).

In the cases of ranger misconduct, for example, the theft of confiscated ivory to sell on illegally (Moreto et al. 2015) or "accepting bribes to help or turn a blind eye to poachers" (Somerville 2016), there are many factors from personal factors to structural or organisational factors that can contribute to that misconduct. Personal factors, for example, range from family traditions of individual rangers to poor decision making (Moreto et al. 2015). In regard to the latter, lack of education, for instance, may hinder rangers' "ability to exercise appropriate conduct when tempted to engage in wrongdoing" (Moreto et al. 2015: 371). Nevertheless, when it came to the main reasoning behind ranger misconduct, it was found that "economic motivations" were an influential factor (Duffy 2014: 830), with rangers being referred to as "money hungry" (EIA 2014; Moreto et al. 2015: 372). However, economic motivations are not always the case in ranger misconduct, which are discussed further below.

Organisational and structural factors that affects ranger misconduct can be from low wages where "bribe money would be used to pay for school fees for rangers' children, [and] other family bills" (Moreto et al. 2015: 373), to inadequate supervision, limited equipment and incomplete training. Most rangers do not have the right training to know what they are looking for, the right equipment to stop poachers or do not have the right supervision to oversee their behaviour and actions (Moreto et al. 2015). In conservation areas and wildlife parks, issues of funding also slow the ability of rangers in stopping poachers as this lack of funds leads to a lack of equipment, lack of staff wages and ultimately lack of morale, which are argued to be detrimental for conservation practices (Bennett 2014; EIA 2014).

The distance between ranger outposts and headquarters can also be a significant factor for misconduct. Moreto et al. (2015) argue that the closer the ranger is stationed to headquarters the less likely they are to do anything for fear of being caught by a superior, whereas those who are stationed in the far outposts are more likely to become poachers themselves. It has also been noted that rangers travel in groups, so to keep the misconduct unnoticed there needs to be a high level of compliance and secrecy between the rangers stationed together. This coupled with low wages further widens the group's susceptibility to bribery (Moreto et al. 2015).

Lastly, socio-cultural factors can also impact upon ranger misconduct. Corruption amongst other government officials, including the police, contributes somewhat to a normative context 
where illegal behaviour and wrongdoing is accepted, "if not expected" due to family ties and traditions (Moreto et al. 2015: 375). This was evident in Uganda when an ivory investigation was hindered by police corruption. Finally, there are also fears of corrupt practices occurring within the local community-by-community leaders, embezzling money from the illicit practices as witnessed during the 1970s and 1980s in West and South Africa (Duffy 2014). For example, in the Kumleben Commission, it was exposed that the South African Defence Force (SADF), during the apartheid era, were involved in poaching and trafficking of ivory to "fund its wars and destabilisation campaigns in South West Africa (now Namibia)" (Duffy 2014: 830). Further to that, it has also been argued that communities located around elephant habitats can have little motive to protect elephants, with locals, often being "bought off by poachers to provide information or help in killing elephants" (Downey 2016).

\section{Transportation}

The transporting of illegal ivory also draws attention to the corrupt practices by those in places of authority. For example, along the Vietnam-China border, there is an estimated $\$ 18,000-\$ 30,000$ a day given out in bribes to border officials to allow illegal ivory to cross borders (Bennett 2014). In Tanzania, six Tanzanian Revenue Authority (TRA) officers were arrested for their involvement in allowing containers filled with ivory to be sealed and then exported out of Tanzania (EIA 2014). This emphasises the notion that "[t]raffickers are attracted to ports where controls are weak or where officials can be bribed" (EIA 2014: 10). Further to that, the EIA (2014): 21) found that there have been incidents involving "naval officers and personnel" from both China and Tanzania accepting bribes for shipments of ivory to be transported across borders without inspection. These examples support that the planning phase of the trafficking process also includes corruption as places or people that can be targeted for bribery are the main routes for smuggling.

Illegal ivory has been found hidden amongst plastic waste, timber and agricultural products where a network of "freight forwarders and shipping agents ensure all of the paperwork is completed and customs officials are paid off" (EIA 2014: 17). Zanzibar used to be the "preferred exit point for ivory smuggling syndicates" (EIA 2014: 23). Now, the Kilindini Port in Mombasa and Jomo Kenyatta International Airport in Nairobi are becoming the top exit points for the trafficking of wildlife, which highlights that the transportation route of poached ivory is forever changing due the expanding transportation networks in countries like Kenya (Weru 2016). It was argued that "since 2009, more ivory has exited through Mombasa than any other trade route out of Africa", destined primarily for Asia, "with transit points in Malaysia, Viet Nam, Thailand and Singapore" (Weru 2016: x). More information about transportation routes is now possible because of the advancements in forensic research. For instance, Wasser et al. (2015) have perfected DNA-based technology that identifies the country or locations of origin of ivory that has been seized. Their research indicates that seizures made in various countries in Asia originated from a range of countries in Central Africa.

Ivory smugglers to obscure the true origin of the shipment use many transit countries in the Middle East, and South and East Asia. They take advantage of the amount of cargo coming in and out of ports, especially in places like Hong Kong "where the sheer volume of trade and the imperative to clear freight quickly means that a small fraction of containers is subject to inspection" (EIA 2014: 26). Also, places such as Mong Cai, Vietnam are also "dominated by organised criminal gangs, aided by corrupt customs and border control officers who charge a fee to wave cargo through unofficial crossings" (EIA 2014: 27). Furthermore, Weru (2016: 16) 
noted that with products such as elephant ivory and rhino horn "wildlife traffickers are able to exploit security loopholes in the country's law enforcement network". Therefore, lax controls and the willingness of officials to take bribes make the smuggling of ivory possible.

\section{Selling}

In addition to taking part in the poaching stage of ivory trafficking, either by poaching themselves or by taking bribes to allow poaching to occur, park rangers have been known to steal elephant tusks that are locked away in the evidence room to make extra money (Moreto et al. 2015). Also, in relation to the selling stage, raw ivory, illegally poached, is regularly sold to wholesalers and craftsmen in unregulated markets and is most often "shipped overseas before being carved into a variety of items" (Lemieux and Clarke 2009: 453). Unregulated markets, facilitated by corruption and civil war, provide an "outlet to sell ivory without international oversight" (Lemieux and Clarke 2009: 454). Registration certificates have become priceless articles of exchange in the ivory trade; vendors have been found selling identification certificates and licences to unlicensed dealers for extortionate prices (Martin and Vigne 2011). Ivory is transported and/or sold on within Africa from the poaching locations towards to the shipping ports (EIA 2015). Ivory is also possibly sold on within Asia after it arrives rather than only being directly imported to the final country of destination. For instance, Nijman and Shepherd (2014) found a lucrative ivory market in Mong La, Myanmar. In an area with no law enforcement and lack of control from the central government, a space exists for ivory to be traded and enter into China with no repercussions (Nijman and Shepherd 2014).

\section{Summary}

There is then substantial evidence indicating that corruption facilitates the illegal ivory trade in relation to planning, poaching, transportation and selling. Whilst there is no direct evidence currently in the literature that documents corruption in the processing and laundering stages, our prediction is that further research would produce proof that corruption features in these stages as well. Furthermore, the evidence above highlights the need for more to be done transnationally to improve law enforcement capabilities at all stages of the market. For instance, new approaches to border control like random inspections might be tried to combat both trafficking and corruption. It has been noted though that random inspections are a hindrance rather than a regulatory tool in stopping the trade. This is because increasing the amount of enforcement often leads to an increase in the number of bribes being handed over (Bennett 2014). Additionally, if judiciary powers are also weak, then even the strongest "regulations do little to enhance good management" instead, it just provides further opportunities for corruption (Bennett 2014: 56). Improved law enforcement and anti-corruption measures then need to be coordinated efforts. More evidence of corruption in wildlife trafficking and the need for synergistic approaches are also evident in the illegal trade of reptile skins.

\section{Reptile (Snake) Skins}

Leather made from reptile skin maybe a small portion of the overall global leather industry, but it is a growing and lucrative market (IUCN 2014). According to the Responsible Ecosystems Sourcing Platform (RESP 2015), over two million reptile skins are traded annually. The leather 
is sourced from more than 25 species of crocodiles, lizards and snakes all listed in one of the CITES appendices. The value of these two million reptile skins is estimated to be around $\$ 6$ billion. There are 25 producing countries and ten transit countries many of which are located within Asia (RESP 2015). In particular, two large python species found in Asia- the Reticulated Python (Python reticulatus) and the Burmese Python (Python molurus bivittatus) - are popular in the industry and have been for nearly 80 years (IUCN 2014). Historically, pythons have been taken from the wild to meet the demand of the leather industry, but in recent years, there has been a shift towards captive breeding. According to the IUCN (2014), there is a growing demand for python skins in the global fashion industry with almost a half million python skins of these two species being exported from Asian countries each year for the last 10 years. Our discussion below will tend to focus on snake skins in particular though, as mentioned, other species of reptiles are used for leather.

\section{Poaching and Breeding}

The trade in most snake skins is governed under CITES. Trade is allowed providing the skins are accompanied by declarations of their origins, including those captured from the wild, captive bred, confiscated or seized or pre-CITES (CIVIC 2013; UNCTAD/CITES 2013). Captive breeding programmes, ranching and wild harvesting are the dominant forms of production. Legal gathering of reptiles and snakes for their by-products is controlled by licences and permits (WWF/TRAFFIC 2015; UNODC 2016) - a system which lends itself to corruption through document fraud (misdeclaring species, number, volume or origin on legitimate paperwork). Licences and permits can also be forged (fake documentation made to look like it is legitimate). Fraud and, potentially to a lesser degree, forgery are corrupt practices, because, as above, they are possible because of the perpetrator's legitimate occupation and abuse of their position. Such abuse of licences and permits allows for the collection or rearing of a greater number of reptiles, thus exceeding annual quotas, and in turn allowing actors involved in this stage of the trade to earn greater profits. This also enables stockpiling of skins, which may be laundered at later stages in the trade. A 2016 case study of the Vietnamese python skin trade found that skins were produced almost entirely through captive breeding programmes (Nossal et al. 2016a). However, wild harvesting of reptiles was not uncommon, and suppliers could not guarantee that small quantities of wild-caught skins were not entering the Vietnamese supply chain. Advances in research of isotopic and elemental markers may help to address questions related to origin and source. Natusch et al. (2017) undertook a study of python skins from Indonesia and Vietnam and were able to identify with 100\% accuracy geographic origins based upon a combination of these markers, leading to a clear distinction between skins coming from the wild versus those coming from captive breeding facilities.

In contrast to Vietnam, a case study on Malaysia found that wild-capture was the predominant form of gathering pythons in their reptile skin trade (Nossal et al. 2016b). This supports findings that many reptiles are captured from the wild by rural actors opportunistically capitalising where sources are high to provide themselves with both primary and secondary incomes (Kasterine et al. 2012; UNODC 2016). In the case of Malaysia, reduced access to European markets has made captive-breeding programmes less economically sustainable than in Vietnam, and wild-capture has emerged as the more profitable method of collection (Nossal et al. 2016b). Around half of all legally traded python skins are believed to come from wild sourced animals. The reticulated python earns collectors around $\$ 4$ per live reptile, an amount greater than for any other single reptile (UNODC 2016). Those collecting legally with a 
licence earn less per reptile, and so the attraction of illegal gathering is clear. As the first stage in the trade, the significance of snakes gathered in this way cannot be overlooked. Skins of unknown origin create difficulties in tracing legality, and whilst the gathering itself may not necessarily entail corruption (abuse of a position of authority or bribery), the presence of reptiles, sourced from the wild, creates opportunity for corruption to occur at later stages in the trade. Legal collection is less profitable than illegal gathering, and so, even though there is potential for profit from rearing snakes and reptiles, as it stands, there is little economic viability in the first stage of collection and/or breeding. For quotas to be more effective in terms of conservation and ensuring livelihoods, there needs to be greater incentives for compliance and greater deterrence for non-compliance.

\section{Processing and Transportation}

In the production of reptile skin products, processing and transportation are closely linked. The live reptiles must first be slaughtered for their by-products in specific facilities. Generally, these slaughterhouses are of a relatively small scale, and so to ensure that their businesses remain economically viable, they may continue to accept live reptiles after surpassing their quotas in order to maintain a business relationship with their collectors (UNODC 2016). As previously mentioned, the excess skins produced may be stockpiled and laundered alongside skins from legally sourced reptiles. There is opportunity for this to occur at the next stage in the production process - the tanning of reptile skins - which occurs in separate facilities. Restrictions on raw skin exports often necessitate the integration of tanneries with registered exporters (UNODC 2016), as evidenced in Indonesia, where the country's 14 skin exporters also operate tanneries (Natusch et al. 2017). The exported processed skins are consequently often later reimported to the country of origin because the skins have been manufactured into a variety of products. As discovered in the case of Malaysia, export restrictions resulted in limited market access, and so to circumvent bans, skins may first be exported to countries, which are allowed to sell skins in European markets (Nossal et al. 2016b), and then re-exported from their destination counties. As shipments provide opportunity for laundering, further exports may facilitate the introduction of more illegally sourced skins into shipments. For instance, Malaysia may export processed skins to Singapore, who has access to the European market. In Singapore, processed skins from several countries and businesses may be combined into a single shipment that is then exported to Italy. In Italy, the processed skins are made into handbags and so forth and some are re-exported back to Singapore and Malaysia. Such complex and frequent shipments create opportunities for (some) legitimate companies to abuse their positions and engage in corrupt practices alongside their legal business.

The high value and low bulk of reptile skins creates high profit margins and the incentive for laundering and smuggling of illegal skins by exporters. Illegally gathered skins can be concealed within shipments of both legal skins and amongst other products. This is facilitated by the use of documentation falsely declaring skin sizes, or origin of skins, or failing to declare skins packaged with other products (Kasterine et al. 2012). Although distribution of skins is monitored through log books (recording quantities amongst other details), false/fraudulent documentation and concealment allow exporters to export greater quantities of skins than permitted (Nossal et al. 2016a). Field research in Indonesia found that tanners and exporters earn the greatest profit from the export of reticulated python skins (UNODC 2016). As mentioned, in Malaysia, the political interference with the trade has resulted in a higher proportion of skins from wild-caught reptiles supplying the industry. This results in skins 
being (re)exported multiple times to avoid the restrictions, creating more opportunities for corruption through bribing of customs and other government officials, laundering and documenting fraud. Not only is the illegal snake skin trade fuelled by the high profit margins for the exporters, but also presumably by the economic motivations of other actors in the supply chain, and facilitated by the poor monitoring and enforcement in regard to exporting (Kasterine et al. 2012).

\section{Selling and Laundering}

As detailed above, by the time reptile skin products have reached the point of sale, various forms of corruption may have already occurred within the supply chain - the literature, however, offers little insight on corruption relating to the selling and proceeds. Whilst corruption significantly facilitates the selling of ivory, there seems to be less corruption at the same stage in the trade of reptile and snake skins. Presumably, this is a reflection of the differing nature of the two markets; the ivory market is nearly completely illegal whilst the majority of reptile and snake skins are destined for use in the luxury fashion market. The misrepresentation through document fraud or forgery occurring earlier in the trade distances the fashion industry from the corruption.

Retailers are, however, aware of the potential presence of illegally obtained skins (UNCTAD 2011). Companies within the fashion industry are taking part of initiatives to address the transparency of sourcing in their supply chain (Responsible Ecosystems Sourcing Platform (RESP) 2016) as discussed below. The profits made by the retailers are likely to be substantially higher than those working in earlier stages of the supply chain, due to the high markup value of the final product. The literature offers no insight into how these profits are distributed, but in order to continue supplying the products, retailers must invest some of the money back into sourcing and processing skins for their final products. In the Vietnamese python skin trade, $25 \%$ of proceeds were used to cover living expenses, or invested back into farms. A further $36 \%$ were used to pay off debts, some of which may have arisen from their participation in the trade (Nossal et al. 2016a). There is also movement by some companies to work directly with the suppliers, which not only may be driven by the desire to cut costs by eliminating the middlemen but may also result in more legally (and ethically) sourced reptiles and snakes (RESP 2016).

\section{Tagging}

Much of the literature makes reference to the proposed tagging systems to combat issues concerning with reptile sourcing and traceability. Such systems could play a significant role in reducing illegality and corruption, in terms of reducing fraud and forgery, in the reptile and snake skin trade. The development of this system was discussed at the 28 th meeting of the CITES Animals Committee (International Institute for Sustainable Development 2015). Various tagging methods were analysed, including labels and RFID tags which would be applied to skins directly; marking holes to perforate skins for identification; and a biometric system. The latter emerged as the most viable due to its applicability, reliability, efficiency and cost of application. It is based on fingerprinting principles and identifies skins through scale pattern and design. It can be applied to skins at an early stage in the trade and is advantageous in its ability to retain sufficient information during the tanning stage, which can negatively impact other proposed tagging systems (CITES 2015b). A tagging system for the identification of 
crocodilian skins has been successfully implemented in Singapore (CITES Resolution Conf. 11.12), which consists of physical tags attached to skins, and is being used on all imports and re-exports of skins. The tagging system is supported by random inspections to ensure compliance (Kasane Conference 2015). Although this works well for crocodilian skins which can be tagged before processing and maintain the tag, this is not the case for other reptile species where physical tags may be more difficult to attach permanently, due to differing compositions of reptile skins. And so, the implementation of tagging systems raises some practical issues, and some key concerns were highlighted at the aforementioned meeting. Mexico and Malaysia highlighted the need to decide what should be measured and how this can be connected with various links in the trade. China cautioned over the use of a universal system. Despite the practical issues of attempting to implement a global traceability system for a wider range of reptile skins, it is not infeasible. However, as highlighted by the USA during the 2015 meeting of the CITES Animals Committee, a more thorough understanding of the trade is needed before pursuing any specific technologies for use, alongside more clear aims for the proposed tagging system to address (IISD 2015). RESP (2016) aims to support CITES in the development and will have a pilot tagging system in place by the end of 2016 .

\section{Summary}

The literature surrounding the trade in reptile skins is focused mainly on ethics and sustainability; there is little concerned with the issue of corruption specifically. There have been some specific case studies, and as there are many variations within the trade between locations, it becomes difficult to create a detailed picture of the situation. What we can see from the existing literature is that the reptile and snake skin trade, as with the greater wildlife trade, are susceptible to corruption through document fraud of permits and licences. The abuse of licences and permits by legitimate businesses in order to exceed annual quotas allows actors to produce more skins than permitted and gain financially. Such abuses are enabled by the lack of controls to stop collection. Further document fraud after the collection stage then misrepresents the illegally obtained skins as being of legal origin. These findings highlight the need for further research looking specifically at corruption within the trade to more accurately determine how document fraud and forgery take place, by whom and what role bribery and gift-giving may have in the illegal trade. Reptile skin products are generally destined for the luxury fashion market, which means retailers have a role to play in combating corruption. The proposed tagging system may be part of this effort as it might prove effective in reducing fraud and forgery and thus laundering. The lack of accountability for actors involved in the trade allows them to turn a blind eye to illegality and engage in corrupt activity by abusing the position of their legitimate business for economic gain. In addition to a tagging system, greater accountability is needed at all stages in the supply chain.

\section{Live Reptile Trade}

Using the model presented throughout this paper, this section aims to highlight the modes of corruption that occur at each stage during the trading of live reptiles. As an overview, since the 1990s, this type of trade has increased enormously both illegally and legally. According to Hoover (1998: 2), upon review of the wildlife trade literature, and numerous press releases from "1970 to 1990 there were only 11 reported investigations of international live reptile smuggling, while from 1991 to 1997 there were at least 23 such cases reported”. Unfortunately, 
the consequences do not outweigh the benefits for smugglers due to the high monetary incentives attached to smuggling wildlife, such as endangered reptiles (Nurse 2015; Wyatt 2013b).

Auliya et al. (2016: 104) state that "of the 10,272 currently recognised reptile species, the trade of fewer than eight per cent are regulated by the Convention on International Trade in Endangered Species of Wild Fauna and Flora (CITES) and the European Wildlife Trade Regulations (EWTR)". Live reptiles are in demand for the international pet trade (Zaldívar Riverón et al. 2002; IUCN 2013), and species wanted as pets may well fall outside of the $8 \%$ that are being internationally monitored. This may mean corruption is unnecessary, as much of the trade is legal and therefore not strictly controlled.

\section{Breeding}

The above-mentioned increase in the illegal live reptile trade did not lead to more research, which means that there is a limited understanding of where and how corruption features along this wildlife trafficking chain. Most suspicion of illegality focuses on the capture or breeding stage at the beginning of the process (Lyons and Natusch 2011; CITES Secretariat 2015). Evidence of misdeclarations related to breeding in captivity have been found. In some cases, the species marked as captive bred are a species that have not been successfully bred in captivity and in other cases the rate of breeding was not possible for the species (TRAFFIC 2012; CITES Standing Committee 2014). One study shows that due to the high demand for exotic reptiles as pets, approximately $76 \%$ of green pythons traded in Indonesia have been sold and exported to breeding farms illegally with the eggs being kept to breed more (Lyons and Natusch 2011). Such intensive harvesting is threatening the species to which Tensen (2016: 293) argues "wildlife farming can only be sustainable" if corruption is not present at any of the trade stages.

In many places when breeding protected species, there is a captive breeding register (Zaldívar Riverón et al. 2002). Again, this may be a point for corruption to occur. Hoover (1998) suggests that breeding farms should be monitored more closely to track their legitimacy. In 2016, CITES members adopted a resolution to address monitoring captive breeding facilities and ranches as these can be sources of fraudulent claims of the species origins (CITES 2016a). For instance, as Nijman and Shepherd (2009) found on their study of captive breeding facilities that species sold in the markets as captive bred could not be located at captive breeding facilities. This reiterates that corruption and lack of enforcement of regional wildlife regulations facilitate the laundering of poached wildlife (Phelps et al. 2013).

\section{Transportation}

There is little evidence to illustrate how corruption features in the transportation stage of the illegal live reptile trade. However, corruption, in the form of false/fraudulent or forged documentation, plays a role in laundering of wild caught species as captive bred in order for the reptiles to be transported without further scrutiny. For example, Auliya et al. (2016: 107) found that one "method of evading CITES regulations" was to camouflage illegally wild caught reptiles "with fraudulent labelling indicating that they have been captive bred" to allow for smooth transportation. Further to that, a study, done by the European Parliament (2016) on the EU trade policy and the wildlife trade, found that coastal routes were also used to smuggle North African reptiles - for the domestic pet industry - into the EU. As outlined above 
regarding the illegal ivory trade, this route is susceptible to corrupt practices. However, as noted previously the corrupt practice - in this case, fraudulent documentation - may have taken place at capture/breeding stage rather than at the transportation stage.

Smugglers have been known to use different methods for trafficking live reptiles, such as using fraudulent packaging descriptions when sending through a courier service and bringing live reptiles in through airports, on their person or in their luggage. There are instances of legal shipments of live reptiles having protected illegal species mixed in with the cargo (Wyatt 2013a). We suggest that using a legal transaction to perpetrate an illegal transaction is an abuse of the employee's or business owner's position and can therefore be considered as a corrupt practice. Corruption may also occur if an inspector during the shipping of the reptiles were to notice and potentially be bribed to allow the shipment to continue unhindered. For example, Vietnam which has been known to be a transit country for reptiles has experienced widespread corruption with corrupt officials accepting bribes or payments for services provided (Wyatt and Cao 2015).

Also noteworthy is that since much of the live trade is legal with different countries having different regulations regarding the shipment of reptiles, a potentially complicated and at times ambiguous regime of permits and licences exists, which further complicates the policing of the illegal transportation. The acceptance of fraudulent export permits means that the import of the illegal reptile is then "legalised". Also, if the illegal reptiles are laundered during the breeding or capture stage, they are viewed as legal when being exported. This may mean that corruption is mostly unnecessary in these later stages since the reptiles are now legal commodities. TRAFFIC (2016) found evidence that the numbers of traded reptiles reported are inconsistent. For example, between the Netherlands and Indonesia, the reported number of exports from Indonesia did not match the reported number of imports to the Netherlands: "A survey of the annual Snake trade expo in Houten revealed 301 unlisted Indonesian reptiles for sale by stallholders from eight European countries".

\section{Selling}

In addition to sales at expos, illegal breeders can be found advertising online and inside magazines. On some occasions, sellers have been known to illegally sell live reptiles under the guise of legal pet shops and reptile fairs (Christy 2008). As with the smuggling of illegal reptiles within legal shipments described above, abusing a legitimate business to traffic wildlife at the fairs could be considered a corrupt practice. This raises the question as to how legal trade can be better controlled. It is not clear who the actors are in terms of the online companies, magazines, pet shop owners and/or the breeders. In the case of online trade, the likelihood is that the illegal online sales are facilitated by volume of sales and difficulty in policing the Internet rather than corruption. This is thought to be the case because there have been a number of agreements signed between the ASA (Advertising Standards Authority) and online platforms to not advertise illegal wildlife. Despite this, in 2015, the Guardian Environment Network reported that the illegal trading of wildlife was still taking place on eBay even though a number of controls had been put in place (Williams 2015).

\section{Summary}

To conclude, there appears to be a lack of consistency in monitoring and adhering to guidelines at each stage of live reptile trading, from the beginning with the issuing of permits to reputable breeders through to transportation. Furthermore, there appears to be little oversight at the end 
stage where proceeds are collected and distributed. With the existence of a large legal pet industry, it appears that some businesses engage in corrupt practices by abusing their legitimate status to also traffic reptiles through fraudulent paperwork and/or smuggling. The consequences for this type of crime do not outweigh the benefits, therefore making it easy and profitable for illegal traders to repeatedly offend. The notable lack of academic and general literature on this issue highlights that there is little concrete detail about corruption in this particular wildlife trade.

\section{Discussion and Conclusion}

Whereas it is largely accepted that corruption is one of the main facilitators of wildlife trafficking, on closer examination, at least of these three cases, very little of the specific mechanisms of corruption have been uncovered. From what is known, within the three cases, notable differences in terms of the trafficking process and the corruption used to facilitate that process are evident (see Table 3). In points along the process where there are permits, the permits are a place for corruption to occur. The corruption taking place consists of breeders/poachers and exporters misdeclaring wild caught versus captive bred, the number of or species being born or transported, or the country of origin. We argue this is corruption rather than simply crime as these acts are only possible because of the abuse of a legitimate position held by the perpetrators. As Williams et al. (2016) propose, this is an entry-point for intervention mechanisms to combat both corruption and wildlife trafficking. Additionally, bribery features along all the trafficking chains as seen in Table 3 to enable smuggling and/or the permit abuse. Patronage may well be present too but it is an under-researched topic in both wildlife trafficking and corruption. Diplomatic cover was only found to play a role in the trafficking of ivory. What Table 3 also makes clear is that very little is known specifically about the planning and laundering stages. Presumably, points along the chain are targeted for corrupt acts (a specific person to be bribed/ permit to be used fraudulently), but this level of detail is unknown. Furthermore, clearly the proceeds of this profitable and prevalent black market are filtering into the legitimate market, but again, very little is known about how this is taking place though attempts are being made to understand the flow of illicit finances (see Maguire and Haenlein 2015).

Planning and laundering in particular are impacted by the societal structures - the criminal justice system and the economic and political environments - featured in Table 2. When the rule of law, political economy and societal/cultural attitudes fail to value or recognise wildlife and do not recognise that wildlife crime is a serious crime, wildlife trafficking and other wildlife crimes continue largely unchallenged. The same can be said of corruption. As Table 2 illustrates, the trafficking process (Table 3 ) sits within the potentially corrupted structures that facilitate wildlife trafficking and other crimes. Context-specific and evidence-based prevention strategies are needed to address both the macro- and micro-level corruption (see Williams et al. 2016 for a discussion).

A necessary and important step that must take place to gain this context specificity and evidence base is for further investigations to be undertaken in Asia and beyond into the diverse range of wildlife trafficking and the corruption involved. Even though a limited overview was able to be given here, what is clear is that these three cases are each unique in how they are structured and how corruption, known or suspected, features are also unique. The uniqueness may stem from the differences in the wildlife and the associated market, but differences, and thus different solutions, will likely also be country specific and also depend upon where in the chain of 


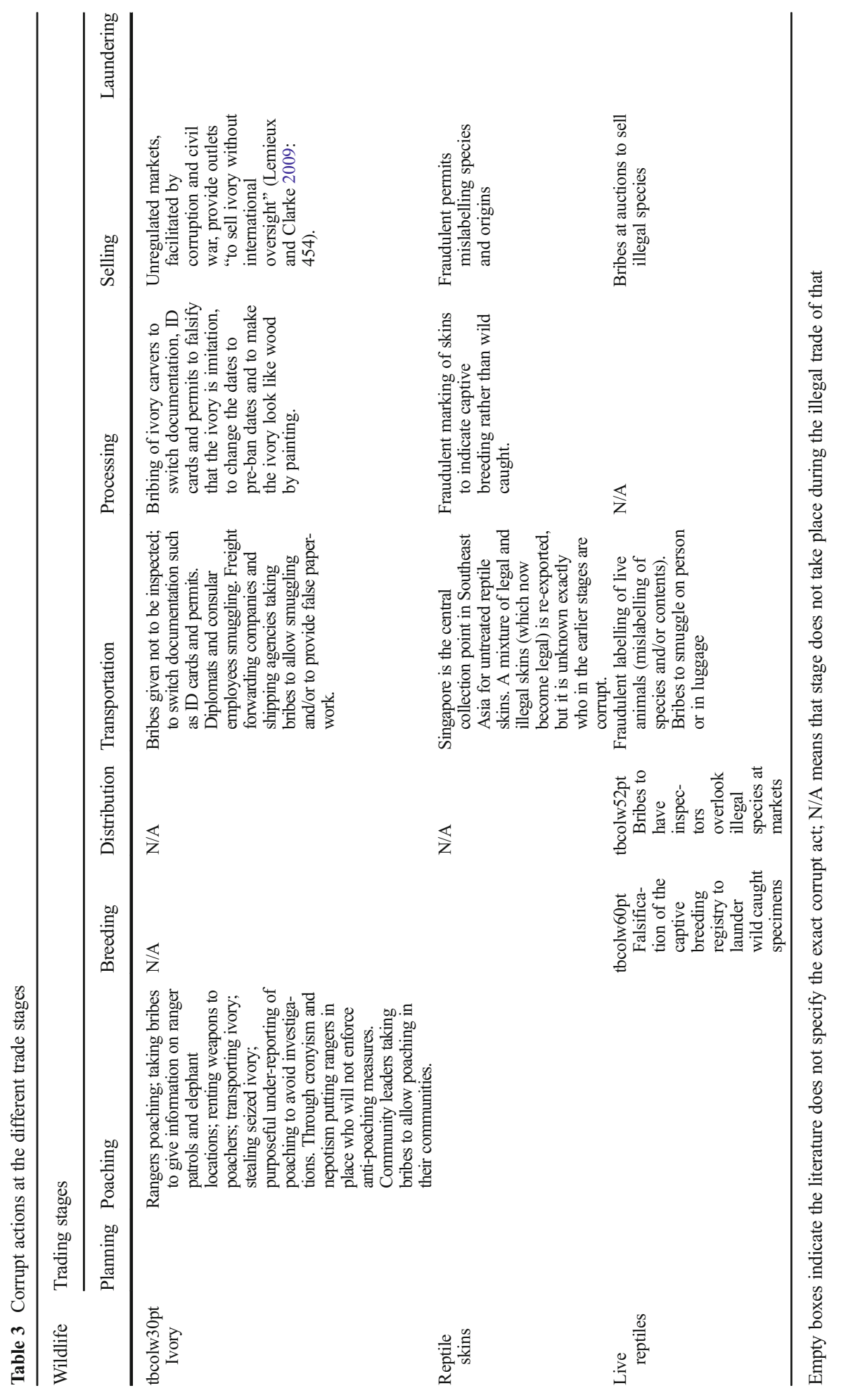


trafficking the corruption takes place. This supports that a one-size-fits-all approach to tackling either and both wildlife trafficking and corruption is unlikely to be effective, and individual casedependent solutions must be developed if the wildlifes targeted by trafficking are to be saved.

Acknowledgements This article came about from a workshop hosted by the "3C Network for Countering Conservation-related Corruption" convened by WWF International, Transparency International-UK and the Durrell Institute of Conservation and Ecology (DICE) at the University of Kent (UK). The authors would like to thank these organisations for having the foresight to tackle these related issues. Particularly, we would like to thank Robby Parry-Jones and Colman O'Criodain for their guidance and comments.

\section{Compliance with Ethical Standards}

Funding This project has not received any funding.

Ethical Approval This article does not contain any studies with human participants or animals performed by any of the authors.

Informed Consent Not applicable.

Conflict of Interest The authors declare that they have no conflict of interest.

Open Access This article is distributed under the terms of the Creative Commons Attribution 4.0 International License (http://creativecommons.org/licenses/by/4.0/), which permits unrestricted use, distribution, and reproduction in any medium, provided you give appropriate credit to the original author(s) and the source, provide a link to the Creative Commons license, and indicate if changes were made.

\section{References}

Atuobi, S. (2007). Corruption and state instability in West Africa: an examination of policy options. KAIPTC Occasional Paper No. 21.

Auliya, M., et al. (2016). Trade in live reptiles, its impact on wild populations, and the role of the European market. Biological Conservation, 10(16), 103-119.

Bennett, E. (2014). Legal ivory trade in a corrupt world and its impact in African elephant populations. Conservation Biology, 29(1), 54-60.

Christy, B. (2008). The lizard king: the true crimes and passions of the world's greatest reptile smugglers. New York: Twelve.

CITES Secretariat. (2015). Enforcement matters. Report of the Secretariat to the Sixty-sixth meeting of the Standing Committee. Geneva.

CITES Standing Committee. (2014). Relationship between ex situ production and in situ conservation: report of the Standing Committee. CoP14 Doc. 48 (Rev. 1).

Common Interventions of the Vulnerabilities in Chains (CIVIC). (2013). The vulnerabilities in the trade chains of flora and fauna protected by the CITES convention. Focus on the trade of timber and reptile skins and their parts and by-products. Available at: http://progettocivic.eu/wp-content/uploads/2014/12/3-CIVICspecie-protetteENGOK.compressed1.pdf. Access 16 Dec 2016.

Convention on the International Trade in Endangered Species of Wild Fauna and Flora (CITES) (2015a) Corruption and the illegal trade in wildlife. Presentation by John E. Scanlon, 6th Session of the Conference of the Parties to the UN Convention Against Corruption. Available at: https:/cites. org/eng/news/sg/cites_sg_presentation_at_the_6th_session_of_the_conference_of_the_parties_to_the_un_ convention against corruption 03112015 . Accessed 27 Sept 2016.

Convention on the International Trade in Endangered Species of Wild Fauna and Flora (CITES). (2015b). Twenty-eighth meeting of the animals committee Tel Aviv (Israel), 30 August-3 September 2015. Available at: https:/cites.org/sites/default/files/eng/com/ac/28/E-AC28-14-02-02Rev.pdf. Accessed 29 Mar 2017. 
Convention on the International Trade in Endangered Species of Wild Fauna and Flora (CITES). (2016a). Implementation of the convention relating to captive-bred and ranch specimens. CoP17 Doc 32. Available at: https:/cites.org/sites/default/files/eng/cop/17/WorkingDocs/E-CoP17-32.pdf. Accessed 19 Dec 2016.

Convention on the International Trade in Endangered Species of Wild Fauna and Flora (CITES). (2016b). Prohibiting, preventing, and countering corruption facilitating activities conducted in violation of the convention. CoP17 Doc 28. Available at: https://cites.org/sites/default/files/eng/cop/17/WorkingDocs/ECoP17-28.pdf. Accessed 19 Dec 2016.

DLA Piper and colleagues (2014) Empty threat: does the law combat illegal wildlife trade? Available at: Accessed 7 June 2016.

DLA Piper and colleagues (2015) Empty threat 2015: does the law combat illegal wildlife trade? Available at: https:/www.dlapiper.com/ /media/Files/News/.../IllegalWildlifeTradeReport2015.pdf. Accessed 5 Nov 2016.

Doig, A., \& Theobald, R. (2003). Introduction: why corruption? In A. Doig \& R. Theobald (Eds.), Corruption and democratisation (pp. 1-12). Portland: Frank Cass.

Downey, H. (2016). TBT: buy ivory, save an elephant?. Property and Environment Research Centre. Available at http://www.perc.org/blog/tbt-buy-ivory-save-elephant Accessed 30th Oct 2016.

Duffy, R. (2014). Waging a war to save biodiversity: the rise of militarized conservation. International Affairs, 90(4), 819-834.

Duffy, R., \& St John, F. (2013). Poverty, poaching and trafficking: what are the links?. Evidence on Demand, Available at: http:/www.evidenceondemand.info/poverty-poaching-and-trafficking-what-are-the-links. Accessed 30 Oct 2016.

Environmental Investigation Agency. (2014). Vanishing point: criminality, corruption and the devastation of Tanzania's elephants. London: EIA Available at: https://eia-international.org/wp-content/uploads/EIAVanishing-Point-lo-res1.pdf. Accessed 20 Mar 2016).

Environmental Investigation Agency. (2015). The Role of corruption in wildlife and forest crime. Available at: https://eia-international.org/report/the-role-of-corruption-in-wildlife-and-forest-crime. Accessed 7 June 2016.

Environmental Investigation Agency. (2016). Time for action: end the criminality and corruption fuelling wildlife crime. Available at: https:/www.corruptionwatch.org.za/wp-content/uploads/2017/02/EIA-Time-for-ActionFINAL-1.pdf. Accessed 7 Mar 2017.

European Parliament (2016) EU trade policy and the wildlife trade. Policy Department. Available at: http://www. europarl.europa.eu/RegData/etudes/STUD/2016/578025/EXPO_STU(2016)578025_EN.pdf. Accessed 29 Apr 2017.

Gossmann, A. (2009). Tusks and trinkets: an overview of illicit ivory trafficking in Africa. African Security Review, 18(4), 50-69.

Gross, L. (2007). In the shadows of the Congo basin forest, elephants fall to the illegal ivory trade. PLoS Biology, 5(4), e115 Available at: http://journals.plos.org/plosbiology/article?id=10.1371/journal.pbio.0050115. Accessed 16 Apr 2016.

Hall, M., \& Wyatt, T. (2017). Capitalisation and gap report: environmental crime and its enforcement in the European Union. Brussels: European Network for Prosecutors for the Environment.

Holmes, L. (2006). Rotten states? Corruption, post-communism, and neo-liberalism. Durham: Duke University Press.

Hoover, C. (1998). The US role in the international live reptile trade: Amazon tree boas to Zululand dwarf chameleons. Available at: http://www.traffic.org/publications/the-us-role-in-the-international-live-reptiletrade.html. Accessed 1 May 2016.

International Institute for Sustainable Development (IISD). (2015). Summary of the Twenty-Eighth Meeting of the CITES Animals Committee: 30 August-3 September 2015. Available at: http://www.iisd.ca/cites/ac28/. Accessed 24 Sept 2016.

International Union for the Conservation of Nature (IUCN). (2013). Red list overview. IUCN red list.

International Union for the Conservation of Nature (IUCN). (2014). Kering and IUCN Boa \& Python Specialist Group announce first report on captive breeding. Available at: https://www.iucn.org/content/kering-andiucn-boa-python-specialist-group-announce-first-report-captive-breeding. Accessed 19 Dec 2016.

Kasane Conference on the Illegal Wildlife Trade. (2015). London declaration on the illegal wildlife tradereview of progress.

Kasterine, A., Arbeid, R., Caillabet, O., \& Natusch, D. (2012). The trade in South-East Asian python skins. Geneva: International Trade Centre (ITC).

Klitgaard, R. (1988). Controlling corruption. Berkeley: University of California Press.

Lemieux, A., \& Clarke, R. (2009). The international ban on ivory sales and its effects on elephant poaching in Africa. The British Journal of Criminology, 49(4), 451-471. 
Lyons, J. A., \& Natusch, D. J. D. (2011). Wildlife laundering through breeding farms: illegal harvest, population declines and a means of regulating the trade of green pythons (Morelia viridis) from Indonesia. Biological Conservation. doi:10.1016/j.biocon.2011.10.002.

Maguire, T., \& Haenlein, C. (2015). An illusion of complicity: terrorism and the illegal ivory trade in East Africa. Royal United Services Institute for Defence and Security Studies. Available at https://rusi. org/sites/default/files/201509_an_illusion_of_complicity_0.pdf. Accessed 30 Oct 2016.

Martin, E., \& Vigne, L. (2011). The ivory dynasty: a report on the soaring demand for elephant and mammoth ivory in southern China. London: Elephant Family, Aspinall Foundation, and Columbus Zoo and Aquarium Available at: http://www.elephantfamily.org/uploads/copy/EF_Ivory_Report_2011_web.pdf. Accessed 13 Mar 2012.

Martin, R., Cumming, D., Craig, G., Gibson, C., \& Peak, D. (2012). Decision-making mechanisms and necessary conditions for a future trade in African elephant ivory. Consultancy for the CITES Secretariat (CITES Notification No. 2011/046). Available at: https://cites.org/eng/com/sc/62/E62-46-04-A.pdf. Accessed 29 Oct 2016.

Martini, M. (2013). Wildlife crime and corruption. U4 Anti-Corruption Resource Centre report. Available at: http://www.u4.no/publications/wildlife-crime-and-corruption/. Accessed 7 June 2016.

Master, D. (2015). Giants Club: Kenya's fight to set up the world's best wildlife law enforcement unit and how a new $£ 64 \mathrm{~m}$ DNA lab is helping battle the poaching business. The Independent. Available at: http://www. independent.co.uk/voices/campaigns/Giants\%20Club/giants-club-kenyas-fight-to-set-up-the-world-s-bestwildlife-law-enforcement-unit-and-how-a-new-64m-10440535.html. Accessed 30 Sept 2016.

Moreto, W., Brunson, R., \& Braga, A. (2015). Such misconducts don't make a good ranger': examining law enforcement ranger wrongdoing in Uganda. British Journal of Criminology, 55(2), 359-380.

Natusch, D., Carter, J., Aust, P., Van Tri, N., Tinggi, U., Mumpuni, A., Riyanto, J., \& Lyons, J. (2017). Serpent's source: determining the source and geographic origin of traded python skins using isotopic and elemental markers. Biological Conservation, 209, 406-414.

Nijman, V., \& Shepherd, C. (2009). Wildlife trade from ASEAN to the EU: issues with the trade in captive-bred reptiles from Indonesia. Brussels: TRAFFIC Europe report for the European commission.

Nijman, V., \& Shepherd, C. (2014). Emergence of Mong La on the Myanmar-China border as a global hub for the international trade in ivory and elephant parts. Biological Conservation, 179, 17-22.

Nossal, K., Livingston, D. G., Aust, P., Kasterine, A., Ngo Viet, C., Nguyen, V., Thai, T., \& Natusch, D. J. D. (2016a). Trade in python skins: impact on livelihoods in Viet Nam. Geneva: International Trade Centre (ITC).

Nossal, K., Livingston, D. G., Aust, P., Kasterine, A., Ngo Viet, C., Nguyen, V., Thai, T., \& Natusch, D. J. D. (2016b). Trade in python skins: impact on livelihoods in Malaysia. Geneva: International Trade Centre (ITC).

Nurse, A. (2015). Policing wildlife: perspectives on the enforcement of wildlife legislation. London: Palgrave Macmillan.

Passas, N. (1998). A structural analysis of corruption: The role of criminogenic asymmetries. Transnational Organized Crime, 4(Spring), 42-55.

Phelps, J., Carrasco, L., \& Webb, E. (2013). A framework for assessing supply-side wildlife conservation. Conservation Biolology., 28(1), 244-257.

Responsible Ecosystems Sourcing Platform (RESP). (2015). Italy and Mexico unveil blueprint for global traceability system for reptile skins. http:/www.resp.ch/news/italy-and-mexico-unveil-blueprint-globaltraceability-system-reptile-skins-2015-07-08. Accessed 19 Dec 2016.

Responsible Ecosystems Sourcing Platform (RESP). (2016). International working group on reptile skins. Available at: http://resp.ch/iwg/reptile-skins. Accessed 3 May 2016.

Smith, R., Biggs, D., St John, F., t Sas-Rolfes, M., \& Barrington, R. (2014). Elephant conservation and corruption beyond the ivory trade. Conservation Biology, 29(3), 953-956.

Somerville, K. (2016). Swaziland - thinking the unthinkable to save rhinos by legalising trade in horn. Institute of Commonwealth Studies. 14th September, Available at http://commonwealth-opinion.blogs.sas.ac. uk/tag/southern-africa/. Accessed 30 Oct 2016.

Tensen, L. (2016). Under what circumstances can wildlife farming benefit species conservation? Global Ecology and Conservation, 6(April), 286-298.

TRAFFIC. (2008). What's driving the wildlife trade? A review of expert opinion on economic and social drivers of the wildlife trade and trade control efforts in Cambodia, Indonesia, Lao PDR and Vietnam. East Asia and Pacific Region Sustainable Development Discussion Papers. Washington, DC: East Asia and Pacific Region Sustainable Development Department, World Bank.

TRAFFIC. (2012). Captive bred or wild taken? Cambridge: TRAFFIC International.

TRAFFIC. (2016). New study highlights significant discrepancies in live animal exports from Indonesia to the Netherlands. Available at: http://www.traffic.org/home/2016/11/21/new-study-highlights-significantdiscrepancies-in-live-anima.html. Accessed 17 Apr 2017. 
Transparency International. (2017). Corruption perception index 2016. Available at: http://www.transparency. org/news/feature/corruption perceptions index_2016. Accessed 7 Mar 2017.

UNCTAD/CITES. (2013). CITES and trade in snake skins. Available at: http://www.biotrade. org/MeetingsEvents/geneva171013/ditcted_171013_meulenaer_en.pdf. Accessed 29 Apr 2016.

United Nations Conference on Trade and Development (UNCTAD). (2011). Improving international systems for trade in reptile skins based on sustainable use. New York: United Nations Publication.

United Nations Conference on Trade and Development (UNCTAD). (2014). Traceability systems for a sustainable international trade in South-East Asian python skins. Available at: http://unctad. org/en/PublicationsLibrary/ditcted2013d6_en.pdf. Accessed 30 Apr 2016.

United Nations Office on Drugs and Crime (UNODC). (2016). World wildlife crime report. Available at: http://www.unodc.org/unodc/en/data-and-analysis/wildlife.html. Accessed 16 Dec 2016.

Wasser, S., Brown, L., Mailand, C., Mondol, S., Clark, W., Laurie, C., \& Weir, B. (2015). Genetic assignment of large seizures of elephant ivory reveals Africa's major poaching hotspots. Science, 349(6243), 84-87.

Weru, S. (2016). Wildlife protection and trafficking assessment in Kenya: Drivers and trends of transnational wildlife crime in Kenya and its role as a transit point for trafficked species in East Africa. TRAFFIC Report, Available at: http://awsassets.wwfdk.panda.org/downloads/kenya report.pdf. Accessed 30 Oct 2016.

Williams, T. (2015). Illegal trade in endangered wildlife thriving on eBay despite controls. The Guardian, $21^{\text {st }}$ April. Available at: https://www.theguardian.com/environment/2015/apr/21/illegal-trade-in-endangeredwildlife-thriving-on-ebay-despite-controls. Accessed 29 Apr 2017.

Williams, A. and Parry-Jones, R. (2016) Corruption and wildlife trafficking: the elephant in the room. Inter Press Service News Agency, Available at: http://www.ipsnews.net/2016/09/corruption-and-wildlife-traffickingthe-elephant-in-the-room/ Accessed 5 Nov 2016.

Williams, A., Parry-Jones, R., \& Roe, D. (2016). The resource bites back: entry-points for addressing corruption in wildlife crime. U4 Issue Paper, November 2016, No 2. Bergen: Chr. Michelsen Institute.

WWF/TRAFFIC. (2015). Strategies for fighting corruption in wildlife corruption: a primer. Available at: http://wwf.panda.org/wwf_news/?257350/Strategies-for-fighting-corruption-in-wildlife-conservation. Accessed 16 Dec 2016.

Wyatt, T. (2013a). The local context of wildlife trafficking: the Heathrow Animal Reception Centre. In D. Westerhuis, R. Walters, \& T. Wyatt (Eds.), Emerging issues in green criminology: exploring power, justice and harm (pp. 108-126). Basingstoke: Palgrave Macmillan.

Wyatt, T. (2013b). Wildlife trafficking: a deconstruction of the crime, the victims and the offenders. Basingstoke: Palgrave Macmillan.

Wyatt, T., \& Cao, A. (2015). Corruption and wildlife trafficking. Bergen: A U4 Anti-Corruption Resource Centre Issue Paper.

Zaldívar Riverón, A., Schmidt, W., \& Heimes, P. (2002). Ficha técnica de Abronia graminea. En: Zaldívar Riverón, A. (compilador). Revisión de las categorías en el proyecto de norma oficial mexicana (PROYNOM- 059-2000) para las especies de lagartijas de la familia Anguidae (Reptilia). Museo de Zoología “Alfonso L. Herrera”, Departamento de Biología, Facultad de Ciencias, Universidad Nacional Autónoma de México. Bases de datos SNIB-CONABIO. Proyecto No. W026. México, D.F. 